\title{
HISTORICISING PENTECOSTAL CHRISTIANITY IN ZIMBABWE
}

\section{Lovemore Togarasei}

Research Institute for Theology and Religion, University of South Africa

Itogarasei@yahoo.com

\section{ABSTRACT}

This paper is a first attempt to systematically present a history of Pentecostal Christianity in Zimbabwe. The paper first discusses the introduction of the Apostolic Faith Mission (AFM) in Zimbabwe before moving on to discuss some of the Pentecostal churches born out of the AFM. This is followed by a discussion of the 1980s and 1990s explosion of American type Pentecostal churches and the current Pentecostal charismatic churches that seem to be sweeping the Christian landscape in the country. The paper acknowledges the difficulty of writing a history of Pentecostalism in the country due to a lack of sources. It identifies AFM as the mother church of Pentecostal movements in Zimbabwe, but also acknowledges the existence and influence of other earlier movements. It has shown that the current picture of Zimbabwean Christianity is heavily influenced by Pentecostalism in mainline churches, African Initiated Churches (AICs) and the various Pentecostal movements.

Keywords: History; Pentecostal Christianity; Apostolic Faith Mission; Zimbabwe; African Initiated Churches

\section{INTRODUCTION}

The past four decades have witnessed a shift in the public expression of Christianity in Zimbabwe. This has been as a result of the explosion of Pentecostal Christianity on the Zimbabwean Christian landscape. Unfortunately, no serious attempt has been made to provide some history of the expression of Christianity in Zimbabwe. Many works have addressed the history of Christianity in Zimbabwe (Baur 1994; Isichei 1995, 115-116; Weller and Linden 1984; Zvogbo 1996). However, most of these

\section{UNISA $\cong$}


great works focus on the history of mainline Christian missions. There are only a few works that address the history of Pentecostal Christianity in the country. Some such works include Gifford (1988), Togarasei (2005), Maxwell (2006) and Verstraelen (1998, 15-16). In trying to build a history of Pentecostalism in Zimbabwe, this paper makes use of some of these works, at the same time trying to bring that history up to date. It has long been observed that the Apostolic Faith Mission (AFM) is the mother of Zimbabwean Pentecostalism (Maxwell 2006; Togarasei 2005). Consequently the paper first discusses the introduction of AFM in Zimbabwe before moving on to discuss some of the Pentecostal churches born out of the AFM. This is followed by a discussion of the 1980s and 1990s explosion of American type Pentecostal churches and the current Pentecostal charismatic churches that seem to be sweeping the Christian landscape in the country.

\section{THE APOSTOLIC FAITH MISSION (AFM)}

Despite being the oldest and still the largest Pentecostal church in Zimbabwe, there is very little that has been written on the history of the AFM. A number of reasons explain this. First, for a long time after its arrival in the country, the church was not recognised by the government. We shall explain why this was the case. However, for this reason and unlike the recognised churches that government sources recorded, nothing much was written on the AFM. Second, it appears the church was led by people who were not sufficiently educated and therefore they did not keep proper records, as was the case with mainline churches like the Catholic Church. The little that was written about the church is probably kept in record in Johannesburg where the church operated from until in the 1940s. ${ }^{1}$ Third, the church did not engage in social services like education and medical health and therefore did not attract much public attention. For this reason an attempt to write the history of this church faces problems of sources. Be that as it may, attempts have been made using archival sources in the form of government records and oral tradition told by old members of this church. Hwata (2005) did some good work on this, noting that 'the history of AFM in Zimbabwe is a reconstruction from recorded interaction between AFM and government authorities' (Hwata 2005, 27). The book by Chandomba (2007) is the only substantive publication on this church. In retelling this history here, I shall make wide use of Chandomba's and Hwata's works as well as my earlier (Togarasei 2010) and Maxwell's (2006) works. Machingura (2011) has also written on the church, but focusing on specific practices, e.g. speaking in tongues, with little on the history of the church. Currently Phillemon Chamburuka (2014) of the University of Zimbabwe is studying this church for his doctoral degree, and we await his findings.

1 Lack of funding did not allow me to go to the Johannesburg offices of the AFM to look for data on some aspects of the church's history. It is possible that access to such archives may help in further developing the history of this church. 
The history of the AFM in Zimbabwe began in South Africa where a group of missionaries led by John G. Lake arrived from the USA on 14 May 1908 (Maxwell 2006, 38). Within a year, and taking advantage of members of the Zionist movement and the 'Pentecostal' revival that had shaken the Dutch Reformed Church, a strong Pentecostal church was established in Johannesburg (Hwata 2005, 21-25; Maxwell 2006, 39-41). With its characteristic of being a 'religion made to travel' (Dempster, Klaus and Petersen 1999) or what Maxwell (2006) calls 'transnationalism' in describing Pentecostal expansion, it was not long before the religion started spreading beyond South Africa. One advantage of South Africa was that, because of the mining activities there, the country attracted a number of migrant workers from the southern African region who, on their return to their native countries, would carry back what they had learnt, acquired and experienced in South Africa. Such included the religion that the migrants would have adopted. Thus it is almost certain that before the recorded case of Zacharias Manamela, who arrived with the Pentecostal gospel in Gwanda in 1915/16, some parts of Zimbabwe had already experienced Pentecostalism through returning migrant workers. Although there is very little record concerning the early days and years of the AFM in Zimbabwe, there is almost a general consensus that Zacharias Manamela laid the foundation for this church. Scholars (Hwata 2005; Maxwell 2006; Togarasei 2010) and popular church history ${ }^{2}$ are agreed on this. The AFM New Life Assembly Church of Chitungwiza, Harare, says the following on the history of the church on their website: 'The work of the AFM in Zimbabwe is said to have begun in 1915 in Gwanda through the preaching of Zacharias Manamela, a convert of the AFM of South Africa.' ${ }^{3}$ Although Manamela's visit was unofficial, his work was soon recognised by the church officials in Johannesburg who tasked Rev. G.J. Booysen from Louis Trichard (Makhado) to seek registration of the church with the Zimbabwean (then Rhodesian) colonial government. Not much is known about the extent of the work of Manamela. It appears he did not stay long in Gwanda as records show that he was soon succeeded by a Mr Kgobe who continued being under the leadership of Rev. Booysen. Kgobe is well remembered for his faith healing practices which unfortunately received criticism from the government authorities resulting in the church failing to get official recognition (Chandomba 2007; Hwata 2005).

Despite the lack of official recognition, the church continued soldiering on with the work. In those early days (1919) they even bought a farm in Gobatema, south of Gwanda. This farm would soon become the base from which the church operated. On several occasions they even tried to open up a primary school but due to lack of recognition, the school was closed by authorities. Four years after Manamela's arrival, AFM work was introduced in Kadoma by a Mr Luttig who

2 See, for example, the history of the New Life Assembly of the Apostolic Faith Mission in Chitungwiza, Harare, Zimbabwe (www.afm-newlifeassembly.org (accessed on 29 June 2012).

3 www.afm-newlifeassembly.org (accessed on 29 June 2012). 
was successful in converting a number of people. Dillon-Malone $(1978,9)$ says Luttig, a European from South Africa, was accompanied by a Nyasa preacher called Dingiswayo. He even attributes the introduction of the AFM in Zimbabwe to Luttig in 1918, although there is now overwhelming evidence that AFM had already been introduced in Gwanda in 1915. Among some of the people he converted were those who would become the early African leaders of this church in Zimbabwe. According to Hallencreutz (1999), Luttig together with two other Pentecostal preachers, M. Bodenhorst and W. Dingesaku, introduced Pentecostalism in Harare, although much of the work around Harare was done by Enock Gwanzura (Togarasei 2010). Despite these efforts, the Pentecostal features of the church (especially glossolalia and faith healing) led it to be denied official status. Authorities complained about the manner in which the preachers of this church operated. Dillon-Malone (1978) cites the Chief Native Commissioner of Kadoma (then Gatooma) district who said in reference to the AFM:

Faith-healing and emotionalism are prominent features of this sect. The psychic and moral effect of such teaching, to my mind, must tend to foster delusions among native community... Emissaries of such sects are a menace to the Administration by stirring up discontent among the natives. (Dillon-Malone 1978, 9)

In the 1920s the overseer of the AFM in Johannesburg, Bosman, even settled in Gobatema to work on church recognition but he was not successful. ${ }^{4}$ Kruger did the same but this time operating from Harare following the South African AFM's decision to make southern Rhodesia a mission field independent from South Africa. Still the church could not be officially recognised. Maxwell (2006) gives a number of reasons why the church was not recognised, but as Togarasei $(2010,21)$ argues: '...the more likely explanation is the political uneasiness that the AFM missionaries caused the colonial state by freely roaming through the reserves without observing the missionary boundaries that the colonial government seems to have instituted.' Related to this was also the fact that the AFM missionary work was not clearly organised and coordinated. The faith healing practices and glossolalia (speaking in tongues) also caused uneasiness among people who were used to mainline formalised worship. Although some kind of coordination was made with the appointment of Kruger as the church overseer based in Harare (then Salisbury), the laissez faire attitude of Pentecostal evangelists continued denting the public image of the church. Hwata $(2005,28)$ could also be right in suggesting that parallels between AFM's glossolalia and faith healing; and traditional spirit possession and witchcraft eradication practices, made the local chiefs and native commissioners to be suspicious of the Christianity preached by the AFM missionaries. Thus the official recognition by the government that Kruger had achieved in early 1931 was withdrawn by 1934 (Togarasei 2010, 21).

4 National Archives of Zimbabwe, File S 1542M 8B1. 
The lack of official recognition did not impede the spread of the Pentecostal gospel in Zimbabwe. By the 1930s one can say the Pentecostal storm was blowing through the country, shaking and disturbing established mainline churches. Eventually the church was given official status through state registration in 1943 under the leadership of Enoch Gwanzura. As has been noted by many scholars (Hallencreutz 1999; Maxwell 2006; Togarasei 2010), this 'pentecostalisation' of Zimbabwean Christianity through the AFM gave birth to a number of African Initiated Churches (AICs). ${ }^{5}$ It also gave rise to other Pentecostal churches that we briefly discuss below.

\section{THE MOTHER GIVES BIRTH: THE RISE OF OTHER PENTECOSTAL MOVEMENTS FROM AFM}

Although the early history of Pentecostal Christianity was characterised by resistance both from the state and from other established churches, by the late 1940s it had spread to many parts of the country. AFM sources (see Hwata 2005) show that by this time the church had members in Harare, Masvingo, Kadoma, Mutare, Zvimba, Domboshawa and many other areas. The official recognition of the church in the 1940s led to proper coordination of church activities and to the establishment of order and discipline. This resulted in those not towing the line of the church leaving the church voluntarily or by expulsion. Mugodhi, who went on to form his own Mugodhi Apostolic Church, for example, was expelled from the church for marrying a second wife against the church's teaching that prohibited polygamy. It is such schisms and expulsions that gave birth to other many apostolic churches (Gunda 2010) and other Pentecostal churches in Zimbabwe. A few such churches are worth mentioning. Madida Moyo broke away in 1945 to form his own Pure Apostolic Faith Mission, Isaac Chiumbu broke away in the same year to form his own African Apostolic Faith Mission, while it can also be argued that Johane Masowe and Johane Maranke were influenced by Pentecostalism to form their apostolic churches (Maxwell 2006). Here we focus briefly on the history of some of these Pentecostal churches. One such church is the Zimbabwe Assemblies of God Africa/ Forward in Faith (ZAOGA/FIF).

We have noted above that the first schisms from the AFM gave birth to AICs. Many of these AICs went on to develop their own theologies, which were to a large extent different from the AFM teaching. ZAOGA, however, remained close to the AFM teaching and so belongs to the category of Pentecostal churches this article addresses. The nucleus of ZAOGA is described by Maxwell $(2006,60)$ as 'young zealots' of humble backgrounds but who focused on being prosperous. As a result, ZAOGA, from the beginning, was different from other AICs as it maintained global Pentecostal characteristics. Togarasei $(2010,19-40)$ describes the church as elitist from the time of its origin. It was associated with urban areas, expanding from there

5 Pentecostal influence on the rise of AICs in Zimbabwe is discussed by Dillon-Malone (1978), Daneel (1987) and Cox (1996) among others. 
to rural areas. It also valued the formal training of ministers, unlike other schisms from the AFM. Ezekiel Guti (the founder of the movement) himself studied in the United States and on his return established a pastoral training centre in Harare. The church also valued material and ideological resources and 'like those elite blacks searching for the means of upward social mobility, they looked abroad for support, inspiration and models of liberation' (Maxwell 2006, 61). Under Ezekiel Guti, ZAOGA would become one of the most successful AFM splinter churches. With Guti having received the vision and instruction to preach in English and the presence of foreign migrant labourers from Mozambique, Malawi, Zambia and other southern African countries, ZAOGA quickly spread beyond the borders of Zimbabwe. It would also spread beyond Africa to such countries as the United Kingdom, United States of America, Australia, and so on. Maxwell (2006) narrates the history of the spread of this church in detail. Despite its transnationalism, the headquarters of ZAOGA FIFI remain in Zimbabwe. The church has also entered what used to be the territory of mainline churches in terms of providing social services to the public. According to the church website, ZAOGA now runs schools, orphanages, a hospital, a television station and a university.

If ZAOGA was a daughter of the AFM, schisms from ZAOGA saw the birth of AFM grandchildren. More Pentecostal movements were born from established ones. Faith World Ministries (FWM) for example can be seen as a grandchild of AFM through ZAOGA. FWM was formed in 1993 when Bartholomew Manjoro, together with his influential wife, Appiah, broke from ZAOGA. In ZAOGA Manjoro was the chief architect of the movement's expansion beyond the Zimbabwean borders. Maxwell (2002, 295-332), based on interviews with him, says Manjoro was instrumental in the expansion of ZAOGA to Zambia, Tanzania, Kenya and West Africa. FWM commands a reasonable following in Zimbabwe and runs a Bible college in Belvedere, Harare. According to the church website, the church has expanded beyond Zimbabwe and has branches in Congo, Tanzania, Zambia, and Malawi, as well as overseas countries such as Japan, Canada and the United Kingdom. ${ }^{6}$ Another Pentecostal church that has come from ZAOGA is the Impact Christian Centre of Bishop David Kanokanga.

Recently a number of new churches have come from the AFM. These include the United Family International Church of Emmanuel Makandiwa; International denominational School of Deliverance of Oliver Chipunza; Heartfelt International Ministries of Tavonga Vutabwashe; and Life House International Church of Talent Chiweshe. We will say more about these churches in our discussion of the current picture of Pentecostal Christianity in Zimbabwe below.

6 www.bishopmanjoro.org/pages/aboutbishop.html (accessed on 8 August 2012). 


\section{FURTHER PENTECOSTAL EXPLOSION: THE RISE OF MORE PENTECOSTAL MOVEMENTS IN ZIMBABWE}

The AFM was not the only church to introduce Pentecostalism in Zimbabwe. Maxwell (1999) mentions the American and South African Assemblies of God and the Pentecostal Assemblies of Canada as some of the Pentecostals that existed early in Zimbabwe alongside AFM. Bond gives some details of Pentecostal assemblies in Zimbabwe in his For the record: Reflections of the Assemblies of God. ${ }^{7}$ He narrates the history of the Assemblies of God in Zimbabwe from 1958 when he was transferred from Durban to Harare (then Salisbury). Bond's reflections confirm Maxwell's point that alongside AFM there were other smaller Pentecostal movements in Zimbabwe as early as the 1950s. He, however, mainly focuses on the establishment of the Assemblies of God among the black population in Harare. This, he says, was done by Nicholas Bhengu, a black South African minister of the Assemblies of God. Bond's work also confirms that one of the Pentecostal churches to operate early in Zimbabwe was the Full Gospel Church of God. This church is believed to have been introduced in Zimbabwe in 1948, having been founded in South Africa in 1910. It was formed as a direct result of the Holy Spirit revival that had taken place in the Dutch Reformed Church. ${ }^{8}$ Others that have their roots in Zimbabwe include Faith Ministries, which was founded by the Scotsman Alistair Geddes. According to Mnkandla (2012), Geddes who came to the then Rhodesia as a member of the British South Africa Police in 1965, went on to study theology at Christ for the Nations in Dallas, Texas, USA in 1971. There he met Guti, the leader and founder of the Zimbabwe Assemblies of God who was also studying there. Geddes's intention for studying theology was to prepare himself for ministry in Rhodesia (Zimbabwe). After a year's training at CFNI, he went back to Zimbabwe together with Guti. He initially worked with Guti but would soon found the Faith Ministries in 1976.

The late 1970s and early 1980s saw the rise of many more Pentecostal churches in Zimbabwe. We will briefly give the history of two such churches which would become major players in Pentecostal Christianity in Zimbabwe. First is the Family of God Church (FOG). The history of FOG goes back to the late 1970s when Andrew Wutawunashe felt God was calling him to begin an African revival in Zimbabwe (Togarasei 2005). Then studying in Sierra Leon, Wutawunashe dropped out of university to go back and start a movement which was typically Pentecostal in its characteristics. Initially operating as Witness Ministries under the Reformed Church of Zimbabwe (former Dutch Reformed Church), Wutawunashe preached in schools, colleges and universities, emphasising the ideas of being born again, speaking in

7 www.nuparadigm.co.za/Bond (accessed on 8 August 2012).

8 www.fullgospelchurch.org.za/index.php?pg=content\&mp=about\&sp=history (accessed on 8 August 2012). 
tongues and performing miracles. He gathered a lot of followers and in 1980 broke away from the Reformed Church, believing that God was calling him to start his own church. The church soon grew in leaps and bounds both in Zimbabwe and outside. In fact in the early 1990s, ZAOGA and FOG dominated the Zimbabwe Pentecostal Christian landscape. With their gospel of health and wealth a number of people, especially the young and upwardly social mobile were attracted to this form of Christianity. Although FOG seems to have lost its magical influence of earlier days, the church still commands a reasonable following in the country and according to their website they are present in 16 countries in Africa, Europe, Asia and the Americas. ${ }^{9}$

\section{THEN CAME AMERICAN TYPE PENTECOSTALISM}

The present picture of Pentecostal Christianity in Zimbabwe shows a lot of American Pentecostal influence: emphasis on gospel of prosperity; individual-centred ministries; radio and television evangelism; print and electronic media crusades advertisement; transnational religious networks; and so on. How did this begin? In his book, The new crusaders: Christianity and the new right in southern Africa, Gifford (1988) argued that the Pentecostal movements in Southern Africa were influenced by the American religious right. He therefore provided some insights into such movements. In the case of Zimbabwe, Gifford discussed the following as Pentecostal movements influenced and propagating American religious right ideals: the Campus Crusade that came to the country in 1979; Youth with a Mission which re-established itself in the country in 1981 after closing doors during the liberation war; the Full Gospel Businessmen's Fellowship International established in the country in 1981; Jimmy Swaggart Ministries which began operating in Zimbabwe in 1985; World Vision International which began an autonomous body in Zimbabwe in 1979; Christ for All Nations which began hosting revivals in Zimbabwe in 1980; the Moonies/Unification Church that began work in Zimbabwe in 1976 but made significant growth after independence in 1980; and the Rhema Bible Church established in Zimbabwe in 1982. Whereas many of the above did not develop to be full churches or did not attract many followers as is the case with the Jimmy Swaggart Ministries, Rhema Bible Church grew to be one of the biggest Pentecostal churches in Zimbabwe. Below I provide a brief history of the growth and current place of this church in Zimbabwean Pentecostal Christianity.

Beginning in 1982, as mentioned above, Rhema Bible Church has gone through two name changes. Rhema was the name given to Tom and Bonnie Deuschle, the founders of this church, when Ray McCauley of the Rhema Church in South Africa prophesied that the two were going to found a church in Zimbabwe (Deuschle 2003, 34). The church was so called until April 1996 when it changed its name to Hear the

9 www.africanrevival.com (accessed on 13 August 2012). 
Word Ministries. Deuschle $(2003,44)$ says this name change was meant to 'reflect our broader outreach'. In 2006, the name changed again to Celebration Ministries following the completion of the Celebration Centre in Borrowdale, Harare. Celebration Church is one of the Zimbabwean Pentecostal churches influenced by American Pentecostalism. As Gifford (1988) observed in its early days: 'Rhema is a classic example of American evangelicalism...Its use of the Bible is typically fundamentalist...The gospel of prosperity is unmistakable; the message is insistent that health and prosperity are the right of every true Christian, so much so that poverty and disease manifest a deficient Christian life.' In the case of this church, American influence is also obvious, as the founder of the church, Tom Deuschle, who is an American graduate of Christ for the Nations International, came to Zimbabwe as a solitary missionary in 1979. Having started with only two families, Celebration Church would later grow into one of the largest Pentecostal churches in Zimbabwe. Today the church boasts several ministries from medical ministries to children, music, television and radio ministries and is present in more than six countries including Ireland and the United Kingdom. ${ }^{10}$

Celebration Church and the other churches and organisations mentioned above are not the only Pentecostal churches in Zimbabwe influenced by American Pentecostalism. In fact, all the so-called 'ministries' in Zimbabwe take a leaf from American Pentecostalism. The characteristics include promoting the gospel of prosperity, emphasis on miracles and especially healing, speaking in tongues as a sign of being born-again, centralisation of power and authority and therefore, to a great extent, mystification of the founder of the ministry and extensive use of media technologies. This brand of Pentecostalism paints the current picture of Pentecostalism in Zimbabwe, as we discuss below.

\section{CURRENT PICTURE OF PENTECOSTALISM IN ZIMBABWE}

In Zimbabwe today, there is no doubt that Pentecostalism is the most dynamic form of Christianity. It is, therefore, no surprise that even mainline churches are also accepting Pentecostal expressions of Christianity in their movements. This was also noted by Omenyo (2006) in Ghana when he talked of 'Pentecost outside Pentecostalism'. Thus there is an array of Pentecostal churches in Zimbabwe today. Chances are that any new church that is formed is likely to have Pentecostal features. Currently the fastest growing church in the country is believed to be Emmanuel Makandiwa's United Family International Church. Founded initially as a non-denominational movement while Makandiwa was still a pastor of the AFM, in 2008 the movement became an independent church. On their website the church claims to have changed

10 www.celebrate.org (accessed on 13 August 2012). 
venues three times in a space of three months to accommodate the growing number of members. ${ }^{11}$ They also claim to have won 17000 members to Christ within that period of three months. At present the church meets at the City Sports Centre in Harare to accommodate the large numbers of people and has established branches in most cities and towns of Zimbabwe.

Another Pentecostal church that has made a mark on the Zimbabwean Pentecostal landscape is the Spirit Embassy of Uebert Angel. Formed in 2007, the church has attracted a number of followers especially due to the founders' claim to prophecy and power to heal. Angel and his wife are known for prophetically identifying people's names, cell phone numbers, residential addresses (including furniture arrangements inside the houses) and even their hobbies and life histories. Angel works closely with Emmanuel Makandiwa and Tavonga Vutabwashe, the founder of Heartfelt International Ministries, another new Pentecostal church. There are also several other Pentecostal churches that include New Life Ministries, River of Life, Zoe Life Changing Ministries, etcetera. International Pentecostal preachers are also well received in Zimbabwe because of many people's inclination to Pentecostal Christianity. In June 2010 when Joyce Meyer held the Festival of Life Conference in Harare, the Harare International Conference Centre was filled to capacity with some people having to be accommodated in tents pitched outside the hall (The Herald 5 June 2010).

About four families of Christian churches are often identified in Zimbabwe (Verstraelen 1998). These are the mainline/historical/missionary churches; African Initiated/Instituted/Independent churches (AICs); Pentecostal; and Evangelical churches. The mainline churches include the Catholic Church and all other missionary Protestant churches, while the AICs include all churches formed by Africans and also mainly attract Africans. This article does not classify AICs under Pentecostal churches, neither does it consider Pentecostal churches initiated by Africans and attracting mainly African members as AICs. I note, however, that the family of Pentecostal churches as it is in Zimbabwe today, is not homogenous. One can identify at least three streams of Pentecostal Christianity in the country. ${ }^{12}$ First are those churches that have come to be known as classical Pentecostal. These are the oldest Pentecostal churches that were introduced in Zimbabwe through missionary activity. They would include the AFM, Full Gospel Church, Assemblies of God and the like. Second are what I often call modern Pentecostal churches (Togarasei 2005). Some scholars refer to them as 'new' Pentecostalism, ${ }^{13}$ others as charismatic Pentecostalism

11 http://ufiministries.org (accessed on 15 August 2012).

12 The business of church typologies is always very difficult as churches have as many similarities as differences. In the Ghanaian context, Omenyo (2006, 94-98), for example, comes up with five types of Pentecostal churches. Discussing Pentecostalism at a global level, Anderson (2010, 13-29) identifies four main and several sub-categories. I accept the subjectivity of my types but believe they give a general picture of Pentecostalism in Zimbabwe.

13 Gifford talks of a 'new' variety of Pentecostalism that emerged in the 1970s, distinguishing it from the classical African Independent Churches which he also calls Pentecostal. 
(Van Dijk 2004, 171), Charismatic Ministries (Asamoah-Gyadu 2005) or just new Charismatic churches. In the Zimbabwean case these include churches that were born from AFM and from American Pentecostal influence. The third stream is the charismatic movement operating within mainline churches. In Zimbabwe, the United Methodist Church has always had charismatic groups that emphasised charismatic/ Pentecostal expressions. Today most mainline churches, including the Anglican Church and the Roman Catholic Church, have such charismatic groups.

\section{CONCLUSION}

Considering the rate at which Pentecostal Christianity is growing in Zimbabwe, it is possible to talk about the pentecostalisation of Zimbabwean Christianity. This paper has endeavoured to provide a history of the growth of this strand of Christianity in the country. It acknowledges the difficulty of doing so, given the lack of sources. The paper identifies AFM as the mother church of Pentecostal movements in Zimbabwe, but also acknowledging the existence and influence of other earlier movements. It has shown that the current picture of Zimbabwean Christianity is heavily influenced by Pentecostalism in mainline churches, AICs and the various Pentecostal movements.

\section{REFERENCES}

Anderson, A. 2010. Varieties, taxonomies and definitions. In Studying global Pentecostalism: Theories and methods. Edited by A. Anderson, M. Bergunder, A. Droogers and C. van der Laan. London: University of California Press.

Asamoah-Gyadu, J.K. 2005. African charismatics: Current developments within independent indigenous Pentecostalism in Ghana. Leiden: Brill.

Baur, J. 1994. 2000 years of Christianity in Africa: An African history 62-1992. Nairobi: Paulines Publication-Africa.

Chandomba, L. 2007. The history of Apostolic Faith Mission and other Pentecostal missions of South Africa. Keynes: AuthorHouse.

Cox, H. 1996. Fire from heaven: The rise of Pentecostal spirituality and the reshaping of religion in the twenty-first century, London: Cassell.

Daneel, M.L. 1987. Quest for belonging: Introduction to a study of African Independent Churches, Gweru: Mambo Press.

Dempster, M.W., Klaus, B.D. and Petersen, D. 1999. The globalisation of Pentecostalism: A religion made to travel. Oxford: Regnum Books.

Deuschle, T. 2003. Building people, building dreams: How a church can change a nation. Harare: Hear the Word Publishing.

Dillon-Malone, C.M. 1978. The Korsten Basketmakers, Lusaka: The Institute for African Studies. 
Gifford, P. 1988. The new crusaders: Christianity and the new right in southern Africa. London: Pluto Press.

Gunda, M.R. 2010. A critical analysis of the survival and relevance of post-colonial African Initiated (Apostolic) Churches. In Faith in the city: The role and place of religion in Harare. Edited by L. Togarasei and E. Chitando, 41-62. Uppsala: Swedish Science Press.

Hallencreutz, C.F. 1999. Religion in the city. In Sites of struggle: Essays in Zimbabwe's urban history. Edited by B. Raftopoulos and T. Yoshikuni, 205-225. Harare: Weaver Press.

Hwata, B. 2005. An investigation of different phases of Pentecostal experience in the Apostolic Faith Mission (AFM). Pretoria: University of South Africa.

Isichei, E. 1995. A history of Christianity in Africa: From antiquity to the present. Grand Rapids: Wm. B. Eerdmans Publishing.

Machingura, F. 2011. The significance of glossolalia in the Apostolic Faith Mission, Zimbabwe. Studies in World Christianity 17(1): 12-28.

Maxwell, D. 1999. Historicizing Christian independency: The southern African Pentecostal movements 1908-1960. Journal of African History 39(2): 243-264.

Maxwell, D. 2002. Christianity without frontiers: Shona missionaries and transnational Pentecostalism in Africa. In Christianity and the African imagination: Essays in honour of Adrian Hastings. Edited by D. Maxwell and I. Lawrie, 295-332. Leiden: Brill.

Maxwell, D. 2006. African gifts of the spirit: Pentecostalism and the rise of a Zimbabwean transnational religious movement. Harare: Weaver Press.

Mnkandla, N. 2012. History: How it all began. In Faith Connection Newsletter, 11-13.

National Archives of Zimbabwe, File S 1542M 8B1.

Omenyo, C.N. 2006. Pentecost outside Pentecostalism: A study of the development of charismatic renewal mainline churches in Ghana. Zoetermeer: Boekencentrum.

The Herald. Zimbabwe newspaper, 5 June 2010.

Togarasei, L. 2005. Modern Pentecostalism as an urban phenomenon: The case of the Family of God Church in Zimbabwe. Exchange: Journal of Missiological and Ecumenical Research 35(4): 349-375.

Togarasei, L. 2010. Churches for the Rich? Pentecostalism and elitism. In Faith in the city: The role and place of religion in Harare. Edited by L. Togarasei and E. Chitando, 19-40. Uppsala: Swedish Science Press.

Van Dijk, R. 2004. 'Beyond the rivers of Ethiopia': Pentecostal pan-Africanism and Ghanaian identities in the trans-national domain. In Situating globality: African agency in the appropriation of global culture. Edited by W. van Binsbergen and R. van Dijk, 171. Leiden, Boston: Brill.

Verstraelen, F. J. 1998. Zimbabwean realities and Christian responses. Gweru: Mambo Press.

Weller, J. and Linden, J. 1984. Mainstream Christianity to 1980 in Malawi, Zambia and Zimbabwe. Gweru: Mambo Press.

Zvobgo, C.J.M. 1996. A history of Christian missions in Zimbabwe. Gweru: Mambo Press.

\section{Electronic references}

www.afm-newlifeassembly.org (accessed on 29 June 2012). 
www.faithministries.net (accessed on 7 August 2012)

www.bishopmanjoro.org/pages/aboutbishop.html (accessed on 8 August 2012).

www.nuparadigm.co.za/Bond (accessed on 8 August 2012).

www.fullgospelchurch.org.za/index.php?pg=content\&mp=about\&sp=history $\quad$ (accessed on 8 August 2012).

www.africanrevival.com (accessed on 13 August 2012).

www.celebrate.org (accessed on 13 August 2012).

http://ufiministries.org (accessed on 15 August 2012). 